\title{
MOTIVASI PERAWAT DALAM MELAKUKAN DOKUMENTASI KEPERAWATAN
}

\section{Aswita Aprililian Sihaloho aswita2002@gmail.com}

\section{Latar Belakang}

Dokumentasi keperawatan merupakan salah satu elemen dari proses keperawatan yang mencatatkan semua data tentang pasien dan yang berhubungan dengan status kesehatan pasien. Dokumentasi yang tepat juga dapat memberi banyak manfaat termasuk meningkatkan kualitas asuhan keperawatan dan tindakan keperawatan menjadi lebih baik dari yang sebelumnya. Dokumentasi keperawatan merupakan bukti pencatatan dan pelaporan yang dimiliki perawat dalam melakukan catatan keperawatan yang berguna untuk kepentingan klien, perawat dan tim kesehatan dalam memberikan pelayanan kesehatan.

Dokumentasi keperawatan merupakan catatan yang dibuat secara tertulis dan dicetak yang berisi tentang catatatan perkembangan kesehatan pasien dan merupakan tugas dan tanggung jawab perawat. Ketidaklengkapan dalam pendokumentasian keperawatan merupaka masalah yang sering muncul. Hal ini terjadi karena tingkat pengetahuan perawat yang masih kurang, dan metode yang digunakan masih manual dengan menulis.

Asuhan keperawatan yang dilakukan perawat dapat terlihat dari hasil dokumentasi keperawatan. Oleh karena itu pelaksanaan asuhan keperawatan merupakan salah satu tolak ukur kualitas pelayanan dari suatu rumah sakit. Hal inilah yang masih memerlukan perhatian bagi para pelaksana asuhan keperawatan. Permasalahan yang sudah ada sejak dulu melekat pada pelayanan keperawatan, dimana perawat merasakan tugas sehari-harinya sebagai suatu rutinitas dan merupakan sebuah intuisi semata. Oleh karenanya perawat yang dapat melaksanakan asuhan keperawatan sesuai standar asuhan mempunyai arti yang sangat penting dalam upaya peningkatan mutu pelayanan. Mutu pelayanan akan sangat dipengaruhi oleh motivasi dan kinerja perawat apabila perawat memperoleh suatu kepuasan kerja sesuai yang diharapkannya (Gibson, et al., 1997). Dokumentasi merupakan wujud nyata yang dapat dievaluasi untuk menentukan baik buruknya asuhan keperawatan yang diberikan pasien.

Pelaksanaan dokumentasi keperawatan merupakan salah satu alat ukur untuk mengetahui, memantau, dan menilai suatu pelayanan asuhan keperawatan yang dilakukan oleh rumah sakit 
(Fischbach, 1991). Dokumentasi keperawatan tidak hanya mencerminkan kualitas perawatan saja tetapi membuktikan pertanggunggugatan setiap tim keperawatan (Potter \& Perry, 2005). Oleh karena itu, jika kegiatan keperawatan tidak didokumentasikan dengan baik, akurat, obyektif, dan lengkap serta sesuai dengan standar asuhan keperawatan maka sulit untuk membuktikan bahwa tindakan keperawatan telah dilakukan dengan benar (Gillies, 2000; Carpenito, 1999).

Sekalipun merupakan tahap akhir proses keperawatan, bukan berarti dokumentasi merupakan hal terakhir yang harus dilakukan perawat terkait dengan status kesehatan pasien. Seperti siklus daur ulang, siklus proses keperawatan juga akan berlangsung berulang melalui dokumentasi keperawatan yang sudah dicatat. Pencatatannya juga bukan hanya formalitas dan menetap, melainkan pencatatan harus selalu akurat dan sesuai dengan tindakan dan hasil yang terdapat sebelumnya.

\section{Metode}

Pengkajian dilakukan dengan mengumpulkan data dari buku, jurnal, dan karya tulis ilmiah lainnya. Referensi yang digunakan akan dicantumkan dengan jelas di daftar pustaka pada bagian akhir kajian. Proses systematic review diawali melakukan penelusuran terhadap artikel jurnal dengan menggunakan desain penelitian kuantitatif, kualitatif maupun mix-method. Penulis melakukan beberapa strategi penelusuran untuk menemukan artikel yang berkaitan dengan pengaruh penerapan sistem pendokumentasian berbasis elektronik terhadap komunikasi perawat. Selama proses penelusuran artikel jurnal penulis menggunakan beberapa kata kunci pencarian. Hasil penelusuran kemudian dilakukan analisis untuk mengidentifikasi dampak positif dan negatif penerapan sistem pendokumentasian berbasis elektronik terhadap komunikasi perawat. 


\section{Hasil}

Hasil pengumpulan data dari sumber yang diteliti merupakan pembahasan utama hal-hal yang terkait dengan dokumentasi keperawatan. Data ini menunjukkan perawat telah menyadari bahwa dokumentasi keperawatan merupakan indikator mutu pelayanan keperawatan. KeperawatanDengan demikian dapat disimpulkan bahwa perawat mempunyai motivasi yang tinggi untuk mencapai mutu palayanan keperawatan yang baik dengan jalan melakukan dokumentasi keperawatan. Dokumentasi keperawatan berbasis elektronik memfasilitasi pertukaran informasi mengenai perkembangan kondisi pasien secara efektif, memberikan bukti pemberian asuhan keperawatan serta menjadi dasar dalam pengambilan keputusan keperawatan Semakin baik pengetahuan tentang dokumentasi keperawatan oleh perawat maka mutu pelayanan kesehatan di fasilitas pelayanan kesehatan juga dinilai baik dan membuat masyarakat puas (Utami dkk,2016). Pengetahuan perawat menentukan tindakan perawat dalam memberikanpelayanan kepada pasien, sehingga tindakan perawat yang dilandasi oleh pengetahuan akan memberikan pelayanan yang lebih baik dibandingkan dengan perawat yang melakukan tindakannya tanpa didasari oleh pengetahuan. Pengetahuan perawat juga sangatberperngaruh terhadap kelengkapan pengisian dokumentasi asuhan keperawatan (Nuryani,2014).

Modifikasi dokumentasi keperawatan juga dapat berupa dokumentasi keperawatan yang dibuat dengan sistem komputer dengan memanfaatkan sistem informasi. Menurut Nahm (2000) menunjukkan bahwa terjadi peningkatan kualitas dokumentasi keperawatan setelah penerapan dokumentasi keperawatan berbasis komputer. Penelitian lain yang dilakukan oleh Gunningberg, et al. (2009) Dokumentasi keperawatan dalam bentuk dokumen asuhan keperawatan merupakan salah satu alat pembuktian atas perbuatan perawat selama menjalankan tugas pelayanan keperawatan. Sehingga dokumentasi asuhan keperawatan menjadi hal yang penting sebagai alat bukti tanggung jawab dan tanggung gugat dari perawat dalam menjalankan tugasnya. Perawat profesional dihadapkan pada suatu tuntutan tanggung jawab yang lebih tinggi dan tanggung gugat setiap tindakan yang dilaksanakan, artinya intervensi keperawatan yang diberikan kepada klien harus dihindari terjadinya kesalahan-kesalahan dengan pendekatan proses keperawatan dan pendokumentasian asuhan keperawatan yang akurat dan benar (Nursalam 2009). 


\section{Pembahasan}

\section{Pengertian Dokumentasi Keperawatan}

Dokumentasi Keperawatan adalah langkah pencatatan pelaksanaan asuhan keperawatan mulai dari pengkajian sampai evaluasi, bahkan mencakup semua tindakan yang dilakukan hingga pasien sehat. Seluruh tindakan yang sudah dilakuakan, dalam pendataannya, harus ditulis dengan susunan yang baik, valid, dan dapat dipertanggungjawabkan.

Efektivitas pelayanan kesehatan tergantung pada sejauh mana pasien dan tenaga kesehatan membangun pemahaman bersama mengenai perkembangan kondisi pasien dan rencana asuhan yang akan diberikan (McCabe \& Healey, 2018). Komunikasi di antara perawat, pasien maupun antar professional pemberi asuhan (PPA) memainkan peran penting dalam menjaga kontinuitas dan kualitas asuhan keperawatan yang diberikan kepada pasien (Itri, Yacob, \& Mithqal, 2017; Park, Le, Pilker, \& Cule, 2018). Selain itu komunikasi yang dilakukan oleh professional pemberi asuhan (PPA) dalam memberikan pelayanan kesehatan kepada pasien merupakan hal yang penting dalam mengoptimalkan keselamatan pasien (Braaf, Riley, \& Manias, 2015). Kepuasan pasien terhadap asuhan keperawatan yang diberikan dapat dicapai melalui pelaksanaan komunikasi efektif. Komunikasi efektif dapat mengurangi resiko insiden keselamatan pasien yang berdampak positif terhadap pasien, peningkatan status kesehatan, mengurangi rasa sakit, kecemasan serta dapat mengurangi waktu rawat inap (Ardakani, MorowatiSharifabad, Bahrami, \& Fallahzadeh, 2019). Salah satu alat komunikasi yang digunakan oleh perawat adalah dokumentasi keperawatan yang berisi informasi tentang kondisi pasien, menggambarkan asuhan keperawatan yang diberikan kepada pasien dan respons pasien terhadap perawatan (Lindo et al., 2016). Penggunaan teknologi dalam kesehatan memberikan banyak manfaat bagi pasien dan perawat untuk meningkatkan keselamatan, efisiensi, dan ketepatan dalam memberikan pelayanan kesehatan (Gaudet \& Howett, 2018). Sistem pendokumentasian berbasis elektronik telah digunakan oleh banyak perawat untuk mendokumentasikan setiap proses keperawatan dan digunakan untuk mendukung profesional perawatan kesehatan dalam memproses, mengelola dan mengkomunikasikan data dalam berbagai kondisi. Sehingga memiliki potensi untuk 
meningkatkan keselamatan pasien, meningkatkan akses profesional kesehatan ke informasi kesehatan pasien, memastikan penggunaan sumber daya yang tepat dan akhirnya dapat meningkatkan komunikasi antara profesional kesehatan (Secginli, Erdogan, \& Monsen, 2014).

\section{Motivasi perawat dalam melakukan dokomentasi keperawatan}

Menurut peneliti pemberian insentif, gaji, peningkatkan karir, keadilan bagian dari motivasi, dapat meningkatkan kinerja individu.Insentif dan gaji diberikan dengan tepat dan adil maka individu memperoleh motivasi dan kepuasan kerja mencapai tujuan, sebaliknya jika insentif atau imbalan diberikan tidak memadai atau kurang tepat maka motivasi dan kepuasan kerja menurun, sesuai dengan pernyataan Riza (2000) bahwa salah satu hal yang menyebabkan motivasi kerja perawat berkurang adalah reward yang kurang. Data mununjukkan bahwa sebenarnya sebagian besar perawat mempunyai motivasi untuk melakukan dokumentasi setiap tindakan yang telah dilakukan ke pasien. Namun demikian di sisi lain sebagian perawat berpendapat merasakan belum adanya jaminan yang kuat dari pihak rumah sakit yang dapat melindungi perawat dari jeratan hukum. Oleh karena itu dokumentasi yang lengkap merupakan tindakan yang tepat untuk melindungi diri dari kasus hukum. Penjelasan tersebut sesuai dengan pernyataan Herzberg (1966 cit. Monica, 1998) yang mengidentifikasikan faktor yang mempengaruhi motivasi seseorang. Terdapat dua faktor yaitu faktor intrinsik dan faktor ekstrinsik. Faktor intrinsik terdiri dari pencapaian, pengakuan, pekerjaan itu sendiri, tanggung jawab, kemungkinan untuk maju (promosi) dan kemungkinan untuk tumbuh (pengembangan diri), sedangkan faktor ekstrinsik terdiri dari kebijakan dan administrasi organisasi, supervisi (penyeliaan), hubungan interpersonal, kondisi kerja, gaji, status maupun jaminan rasa aman.

\section{Tujuan dan Manfaat Dokumentasi Keperawatan}

Tujuan dilaksanakannya pendokumentasian keperawatan aadalah ssebagai berikut.

A. Menghindari ketidaktepatan seperti kesalahan, tumpang tindih tindakan, mupun data yang tidak lengkap. 
B. Membina koordinasi dan kolaborasi yang baik antar petugas pemberi layanan kesehatan.

C. Meningkatkan profesi keperawatan yang efektif.

D. Menjamin kualitas asuhan keperawatan

E. Pertanggungjawaban oknum yang tepat dalam bidang hukum.

F. Data yang akurat untuk dijadikan penelitian ilmiah (bidang pendidikan) dan perbaikan standar keperawatan yang berlaku.

G. Menjauhkan tindakan malpraktik dalam tindakan/asuhan keperawatan.

Manfaat dilaksanakannya pendokumentasian keperawatan adalah sebagai berikut.

A. Bagi klien/pasien. Pelayanan yang diberikan oleh petugas pelayan kesehatan merupakan yang berkualitas tinggi dan sesuai dengan klien. Dalam hal ini juga kerap kali dilakukan pematangan dan penilaian agar perencanaannya menjadi yang paling tepat dan terarah.

B. Bagi perawat. Keaktifan dan keefektifan kerja perawat dalam tindakan mandirinya dapat lebih dioptimalkan lagi. Perawat akan merasakan kepuasan tersendiri karena lengkapnya dokumentasi tindakan yang telah dilakukan dapat meningkatkan motivasi perawat untuk menjadi lebih baik lagi.

C. Tim kesehatan lain. Kelengkapan data dari suatu tim kesehatan akan membantu bidang lain dalam melakukan pekerjaan dan tindakannya terhadap pasien.

D. Instansi kesehatan. Citra instansi pemberi layanan kesehatan, seperti rumah sakit atau klinik, akan lebih baik dengan adanya dokumentasi yang baik. Dengan peningkatan mutu yang dilakukan secara terusmenerus, instansi juga dapat merasakan efek dari kepuasan pasien dan pelayanan yang bermutu tinggi yang telah diberikan oleh perawat, yang tertera dalam dokumentasi keperawatan.

\section{Standar Dokumentasi}

Keperawatan Standar diperlukan untuk mengarahkan atau memedomani pembuatan dan penulisan dokumentasi keperawatan. Standar keperawatan secara internasional dapat dilihat dari adanya satndar seperti NANDA, NIC, dan NOC. A. NANDA (North American Nursing Diagnosis Association). Merupakan standar yang diakui 
untuk mengidentifikasi masalah kesehatan dan kebutuhan pasien. Di dalamnya terdapat spesifikasi yang berhubungan dengan kebutuhan fisik, sosiologi, dan juga psikologi. B. NIC (Nursing Intervension Clasification). Berisi tindakan sesuai dengan kondisi yang terdaftar. Ini dapat digunakan perawat untuk membantu klien dalam peningkatan status kesehatan dan mencapai kriteria dan hasil akhir yang diharapkan. C. NOC (Nursing Outcome Clasification). NOC sudah diakui sebagai standar opedoman yang dapat memberi kriteria hasil akhir, fokus yang jelas namun dapat digunakan secara luas, menampilkan spesifikasi status kesehatan, serta memiliki faktor risiko yang luas namun akurat. Standar lain dalam keperawatan yang juga diakui adalah:

A. Komunikasi. Yaitu dengan mencatat informasi secara akurat, relevan, dan komprehensif. Catat semua aspek proses keperawatan baik informasi subjektif maupun objektif. Pastikan tulisan dapat dibaca dan dimengerti oleh orang lain bahkan oleh diri sendiri, serta mengurangi terdapatnya data ganda.

B. Akuntabilitas. Yaitu denga mematuhi etika, standar profesional, dan peraturan yang berlaku di instansi kesehatan tempat perawat bekerja. Lakukan pendokumentasian sesegera mungkin setelah dilakukannya tindakan dengan menuliskan secara lengkap tanggal, waktu, dan catatan lainnya sesuai dengan konologis. Jangan meninggalkan baris kosong atau dengan kata lain harus menutup/mengisi baris kosong tersebut. Sekalipun terdapat kesalahan penulisan yang dilakukan, perawat hanya dapat memperbaiki kesalahan penulisan tersebut tanpa harus 3 menghapus bagian yang salah. Demikian juga dengan adanya kesalahan kegiatan, perawat harus mencatatnya dengan baik.

C. Keamanan dan kerahasiaan. Yaitu dengan melindungi informasi klien dan menyimpannya sebagai arsip dengan aman. Akses ke tempat penyimpanan data klien juga harus dijaga dengan aman. Jikapun harus menggunkan data pasien, identitas asli pasien sangat tidak dianjurkan untuk digunakan secara terangterangan. Hal ini juga tentunya harus diketahui oleh klien. Pertahankan catatan sebagai tanggung jawab perawat hingga pada harus dihancurkannya dokumen tersebut tetap dipertanggungjawabkan dan berstatus rahasia. 


\section{Prinsip Dokumentasi Keperawatan}

Pusat Pendidikan Sumber Daya Manusia Kesehatan Republik Indonesia mencatat bahwa prinsip-prinsip yang berlaku dalam melakukan pendokumentasian keperawatan adalah sebagai berikut.

A. Dokumentasi adalah suatu bagian integral dalam proses keperawatan terkait asuhan keperawatan.

B. Sifat dari kegiatan dokumentasi harus konsisten.

C. Dalam kegiatan dokumentasi keperawatan diperlukan format yang sesuai.

D. Dokumentasi keperawatan hanya dapat dilakukan oleh yang melakuka tindakan atau melakukan observvasi secara langsung kepada pasien.

E. Dokumentasi harus dibuat sesegera mungkin.

F. Catatan dalam dokumentasi harus memuat kronologis yang tepat.

G. Dalam penulisan istilah singkatan, singkatan tersebut haruslah merupakan singkatan yang sudah dimengerti secara umum.

H. Sertakan tanggal, waktu (jam), tanda tangan, dan inisial perawat dalam dokumentasi.

I. Penulisan catatan harus bersifat akurat, benar, kompit, jelas, ringkas, dapat dibaca, dan ditulis dengan pulpen/tinta.

\section{Penutup}

Terdapat hubungan yang bermakna antara motivasi intrinsik perawat pelaksana dengan pelaksanaan pendokumentasian asuhan keperawatan. Asuhan keperawatan yang dilakukan perawat dapat terlihat dari hasil dokumentasi keperawatan. Oleh karena itu pelaksanaan asuhan keperawatan merupakan salah satu tolak ukur kualitas pelayanan dari suatu rumah sakit. Hal inilah yang masih memerlukan perhatian bagi para pelaksana asuhan keperawatan. Permasalahan yang sudah ada sejak dulu melekat pada pelayanan keperawatan, dimana perawat merasakan tugas sehari-harinya sebagai suatu rutinitas dan merupakan sebuah intuisi semata. Oleh karenanya perawat yang dapat melaksanakan asuhan keperawatan sesuai standar asuhan mempunyai arti yang sangat penting dalam upaya peningkatan mutu pelayanan. Mutu pelayanan akan sangat dipengaruhi oleh motivasi dan kinerja perawat apabila perawat memperoleh suatu kepuasan kerja sesuai yang diharapkannya. 


\section{Daftar Pustaka}

Handayaningsih, I. (2019). Dokumentasi Keperawatan" DAR" Panduan, Konsep, dan Aplikasi.

Noorkasiani, N., Gustina, R., \& Maryam, S. (2015). Faktor-Faktor yang Berhubungan dengan

Kelengkapan Dokumentasi Keperawatan. Jurnal Keperawatan Indonesia, 18(1), 1-8.

Sugiyati, S. (2014). Hubungan Pengetahuan Perawat dalam Dokumentasi Keperawatan dengan Pelaksanaannya di Rawat Inap RSI Kendal. In PROSIDING SEMINAR NASIONAL \& INTERNASIONAL (Vol. 2, No. 1).

Triyanto, E., \& Kamaluddin, R. (2008). Gambaran Motivasi Perawat dalam Melakukan Dokumentasi Keperawatan di RSUD Prof. Dr. Margono SOekarja Purwokerto. Jurnal Keperawatan Soedirman, 3(2), 66-80.

Wirawan, E. A., Novitasari, D., \& Wijayanti, F. (2013). Hubungan antara supervisi kepala ruang dengan pendokumentasian asuhan keperawatan di rumah sakit umum daerah ambarawa. Jurnal Manajemen Keperawatan, 1(1).

Zakiyah, A. (2015). Hubungan Sikap dan Karakteristik Perawat Dengan Pendokumentasian Asuhan Keperawatan di Rumah Sakit Umum Sidoarjo. Jurnal Keperawatan Sehat, 5(01).

Passya, P., Rizany, I., \& Setiawan, H. (2019). Hubungan Peran Kepala Ruangan dan Supervisor Keperawatan dengan Motivasi Perawat dalam Melakukan Dokumentasi Keperawatan. JURNAL KEPERAWATAN RAFLESIA, 1(2), 99-108.

Pakudek, K. H., Robot, F., \& Hamel, R. (2014). Hubungan motivasi perawat dengan pelaksanaan dokumentasi asuhan keperawatan di instalasi rawat inap C RSUP Prof. Dr. RD Kandou Manado. Jurnal Keperawatan, 2(2).

Diyanto, Y. (2007). Analisis faktor-faktor pelaksanaan dokumentasi asuhan keperawatan di Rumah Sakit Umum Daerah Tugurejo Semarang (Doctoral dissertation, program Pascasarjana Universitas Diponegoro). 
Siswanto, L. H., Hariyati, R. T. S., \& Sukihananto, S. (2013). Faktor-Faktor yang berhubungan dengan kelengkapan pendokumentasian asuhan keperawatan. Jurnal Keperawatan Indonesia, 16(2), 77-84.

Simamora, R. (2009). Dokumentasi Proses Keperawatan.

Simamora, R. H., Purba, J. M., Bukit, E. K., \& Nurbaiti, N. (2019). Penguatan Peran Perawat Dalam Pelaksanaan Asuhan Keperawatan Melalui Pelatihan Layanan Prima. JPPM (Jurnal Pengabdian Dan Pemberdayaan Masyarakat), 3(1), 25-31. 